UDC 616-089.819.843

Ivolgin D. A. ${ }^{1,2}$, Smolyaninov A. B. ${ }^{1,2}$

${ }^{1}$ Research laboratory of cell technologies of the Northwest State Medical University I.I. Mechnikov, St. Petersburg,

Russian Federation

${ }^{2}$ Pokrovsky stem cell bank, St. Petersburg, Russian Federation

e-mail: ida59m@mail.ru

\title{
ISOLATION OF NUCLEATED CELLS FRACTION FROM UMBILICAL CORD BLOOD - CHOICE OF METHOD
}

\section{ABSTRACT}

The comparison of different techniques for cord blood processing to ensure the highest cell yield based on the «cost-effectiveness» ratio is important.

A study of the effectiveness of nucleated cells fraction isolation from umbilical cord blood samples $(n=2898)$ using double centrifugation, automatic (Sepax S100, Biosafe) or semi-automatic (MacoPress Smart, MacoPharma) separation system was performed. The followings were determined: nucleated cells number (per $\mathrm{ml}$ and total), the number of $C D 34^{+}$cells and cell viability before samples treatment, after treatment and before freezing.

It was shown that semi-automatic and automatic processing methods were more efficient than double centrifugation by key quality indicators of cell concentrates: the total number of nucleated cells and nucleated cells yield. The semi-automatic method of nucleated cells fraction isolation requires the least time for processing a single sample.

Considering these data, such a system has been proposed as optimal for daily receipt and processing of cord blood samples in a cord blood bank.

KEYWORDS: umbilical cord blood, cord blood bank, cell separation semi-automated system

Umbilical cord blood (CB) is now recognized as one of the main sources of stem cells for the treatment of various diseases. Apart from the advantages as compared to other sources of stem cells (bone marrow, peripheral blood), CB has a relatively limited number of hematopoietic cells [1,2]. Since the outcome of transplantation depends on the number of transplanted cells [3], there is a need to minimize the loss of cells during sample processing. Studies held in CB banks to increase the efficiency of total nucleated cells (TNCs) allocating can significantly improve the outcomes of stem CB cell transplantation $[4,5]$.

The idea of processing (volume reduction) of CB placed for a longterm cryostorage, belongs to the founder of the first public cord blood bank Professor P. Rubinstein (1995). Intact CB was placed for storage before.

Processing of $C B$ pursued the reduction of storage space and related costs; and the reduction of cryoprotectant addition into CB sample to lower its side effects in transplantation. The first approach to reduce the CB sample volume became the double centrifugation method [6]. This method and its modifications [7, 8] are used to date. They are a standard for comparing the efficiency of TNCS fraction allocation with other techniques.

The next step in improving of $\mathrm{CB}$ processing technology has been the emergence of so-called semi-automatic systems «top-and-bottom», originally used for the fractionation of peripheral blood [9]. The examples of such systems are "Optipress II» (Baxter, USA) and Compomat G4 (Fresenius, Germany). To date, these systems are widely used to extract a fraction of TNCs out of CB [10-13]. Their effectiveness was evaluated in the framework of technological solutions of semi-automatic separation systems [14], and in comparison with other CB processing methods [15, 16]. Experience shows clear perspectives of semi-automatic systems [17] to satisfy high and stable CB cells yield. Furthermore, the use of semi-automatic $\mathrm{CB}$ processing systems significantly reduces the risk of contamination and damage of CB container [18]. Since 2000 along with the use of semi-automatic systems there were used fully automatic ones, such as Sepax S-100 (Biosafe, Switzerland) [19, 20]. Using this cell separator, a number of manipulations with $\mathrm{CB}$ is reduced comparing to the semi-automatic systems. In addition, such an apparatus has programs allowing the selection of the cell concentrate from small CB sample and washing off the cryoprotectant from thawed cell concentrate. There are other CB processing methods, but they are not widely available at the moment [21].

Nevertheless, in a CB bank, treatment and storage organization of $\mathrm{CB}$ samples should consider not only the effectiveness of various methods to extract a fraction of TNCs out of $\mathrm{CB}$, but also costs of equipment and supplies, and processing time. 
The aim of our study is to compare different CB treatment methods for organizing the activity of stem cells isolation laboratory, providing the highest possible yield of TNCs and consider the «cost-effectiveness» ratio.

\section{MATERIALS AND METHODS}

The study was based on retrospective quantitative and qualitative analysis of the CB samples $(n=2898)$ collected in obstetric institutions of St. Petersburg, Leningrad region and other cities of the Russian Federation. All the CB samples were delivered, processed, frozen and stored for long periods in cell technologies laboratory in I. I. Mechnikov Northwestern State Medical University and Pokrovsky stem cell bank as a part of a public CB storage creation. All CB samples were collected during delivery at term and cesarean section.

Isolation of stem cells from CB samples was performed in the following ways:

Group I $(\mathrm{n}=1797)$ - double centrifugation method [6] in the modification of the American Association of Blood Banks [22];

Group II $(\mathrm{n}=1012)$ - automatic system Sepax S100 (Biosafe, Switzerland);

Group III $(\mathrm{n}=78)$ - semi-automatic system MacoPress Smart (MacoPharma, France).

\section{Laboratory methods}

In accordance with international standards of $\mathrm{CB}$ harvesting [8, 23], there are required researches of qualitative $C B$ indexes during its processing. These include the determining of the total number of nucleated cells (TNCs), the number of CD34+ cells, and cell viability. In this study we carried out researches of $\mathrm{CB}$ samples on the following parameters:
- before treatment - TNCs count using hematological analyzer Coulter AcT diff 2 (Beckman Coulter, USA);

- after treatment and before freezing - count the TNCs using by hematological analyzer, count the number and viability of $\mathrm{CD}_{3} 4^{+}$cells (per unit volume and absolute) using flow cytometer FC500 (Beckman Coulter, USA) with software CXP and Stem-Kit reagents (Beckman Coulter, USA). TNCs yield after treatment was calculated as percent of the amount before their treatment.

\section{Statistic methods}

Statistical analysis was carried out on parametric and nonparametric statistical techniques $[24,25]$. To determine the normal distribution of variables Kolmogorov-Smirnov test was conducted [26, 27].

Statistical analysis was performed using Student's t-test and U-MannWhitney test. The critical level of significance was $p<0.05$. We used a standard software package Microsoft Office Excel 2003 for MS Windows version 1.0, SPSS for MS Windows version 19.

\section{RESULTS AND DISCUSSION}

Baseline characteristics of umbilical cord blood samples, which were later processed with double centrifugation, automatic and semi-automatic separation, are shown in Table. 1.

The values of t-test in groups, characterizing the volume of $\mathrm{CB}$, the number of TNCs/ $\mathrm{ml}$ and TNCs in the CB sample, did not differ significantly.

Results of $\mathrm{CB}$ processing using double centrifugation, semi-automatic method and automatic system are presented in Table 2.

The value median of some indicators in the groups of semi-automatic treatment and automatic separation exceeds the values obtained

Table 1. Baseline characteristics of cord blood units before treatment $(\mathrm{M} \pm \mathrm{m})$

\begin{tabular}{|c|c|c|c|c|}
\hline GROUP & PROCESSING METHOD & $\begin{array}{l}\text { CORD BLOOD } \\
\text { UNIT VOLUME, ML }\end{array}$ & $\begin{array}{l}\text { NUCLEATED CELLS NUMBER, } \\
\text { X10 } 10^{6} \text { CELLS/ML }\end{array}$ & $\begin{array}{c}\text { ABSOLUTE NUMBER } \\
\text { OF NUCLEATED CELLS, } \\
\text { X10 } 10^{6} \text { CELLS }\end{array}$ \\
\hline I & Double centrifugation $(\mathrm{n}=1797)$ & $111,8 \pm 0,8$ & $11,4 \pm 0,08$ & $1286,4 \pm 13,4$ \\
\hline II & Automatic separation $(n=1012)$ & $110,9 \pm 0,2$ & $11,1 \pm 0,16$ & $1235,8 \pm 23,2$ \\
\hline III & Semi-automatic separation $(n=78)$ & $111,1 \pm 0,4$ & $11,2 \pm 0,08$ & $1266,6 \pm 18,9$ \\
\hline
\end{tabular}

Table 2. Cord blood characteristic after treatment (Me and range of deviation)

\begin{tabular}{|c|c|c|c|c|c|c|c|}
\hline GROUP & PROCESSING METHOD & $\begin{array}{l}\text { NUCLEATED } \\
\text { CELLS NUMBER, } \\
\text { Х10' КЛ/MЛ }\end{array}$ & $\begin{array}{l}\text { ABSOLUTE } \\
\text { NUMBER OF } \\
\text { NUCLEATED } \\
\text { CELLS, } \\
\text { X10 }{ }^{6} \text { CELLS }\end{array}$ & TNCS YIELD, \% & $\begin{array}{c}\text { CD34+ CELLS } \\
\text { NUMBER, } \\
\text { X10 }\end{array}$ & 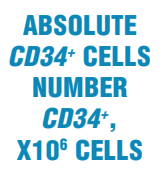 & VIABILITY,\% \\
\hline \multirow{2}{*}{ I } & \multirow{2}{*}{$\begin{array}{l}\text { Double centrifugation } \\
\qquad(n=1797)\end{array}$} & 39.2 & 860,0 & 73,0 & 0,09 & 1,95 & 98,6 \\
\hline & & $2,5-93,1$ & $50,0-2000,0$ & $47,3-98,2$ & $0,002-0,31$ & $0,05-6,6$ & $96,6-100,0$ \\
\hline \multirow{2}{*}{ II } & \multirow{2}{*}{$\begin{array}{l}\text { Automatic separation } \\
\qquad(n=1012)\end{array}$} & $43,3^{*}$ & $905,3^{*}$ & 81,9 * & $0,11^{*}$ & 2,1 & 99,2 \\
\hline & & $12,5-95,0$ & $247,1-1950,0$ & $65,1-97,6$ & $0,005-0,4$ & $0,09-7,5$ & $96,6-100,0$ \\
\hline \multirow{2}{*}{ III } & \multirow{2}{*}{$\begin{array}{l}\text { Semi-automatic separation } \\
\qquad(\mathrm{n}=78)\end{array}$} & $42,3^{*}$ & $891,8^{*}$ & $81,7^{*}$ & 0,1 & 1,9 & 99,1 \\
\hline & & $8,5-83,5$ & $669,0-1787,1$ & $61,7-94,4$ & $0,003-0,4$ & $0,07-6,8$ & $96,5-100,0$ \\
\hline
\end{tabular}


by processing $C B$ with double centrifugation. There were significant differences between TNCs number per sample, TNCs number per ml, TNCs yield from the basic amount comparing these groups with group I. The number of $C D 34^{+}$cells per $\mathrm{ml}$ was significantly higher in group II then in group I. Automatic CB processing systems did not reduce the viability of nucleated cells. There were not found any significant differences in groups II and III.

The findings suggest that semi-automatic and automatic separations are more effective in selection of TNCs fractions from CB then double centrifugation method.

Time spent on selection of TNCS fraction from a CB sample was following: double centrifugation - 27.25 min, automatic processing -54 min, and semi-automatic - $25.7 \mathrm{~min}$.

Comparing the expenses (all prices are according to distributors), a double centrifugation method requires a refrigerated centrifuge (780 thousand RUR) and consumables (blood container) at the rate of 27 RUR per sample. For automatic CB separation it is necessary to purchase system Sepax S100 (2.3 million RUR) and one-time processing systems at the rate of $6150 \mathrm{RUR}$ per sample. The cost of semi-automatic separation method consists of 1.3 million RUR for an equipment and 1,650 RUR per isolation of one TNCs from CB sample.

Thus, the use of semi-automatic and automatic systems for $\mathrm{CB}$ processing can increase the amount of isolated TNCs. Selection of a particular method of CB processing belongs to the bank and depends on several factors: a number of employees, a number of CB samples received and processed per day, the possibility of timely procurement of consumables, equipment and service etc. These results can be taken into account in organizing activities of cord blood banks. Considering the experience of Pokrovsky stem cell bank in the daily receipt and processing of 5 and more CB samples, we should propose a system of semi-automatic separation Macopress Smart (MacoPharma, France) as an effective and requiring minimal time to process a CB sample.

\section{CONCLUSIONS}

1. SEMIAUTOMATIC MACOPRESS SMART (MACOPHARMA, FRANCE) AND AUTOMATIC SEPAX S100 (BIOSAFE, SWITZERLAND) SYSTEMS PROVIDE A SIGNIFICANTLY HIGHER YIELD OF NUCLEATED CELLS FRACTION FROM CB COMPARED TO THE DOUBLE CENTRIFUGATION METHOD; AND THEY ARE COMPARABLE IN EFFICIENCY.

2. SEMI-AUTOMATIC SYSTEM MACOPRESS SMART (MACOPHARMA, FRANCE) REQUIRES THE LEAST TIME AND MEETS «COST-EFFECTIVENESS» CRITERION.

\section{REFERENCES}

1. Gluckman E, Rocha V, Arcese W, et al. Factors associated with outcomes of unrelated cord blood transplant: Guidelines for donor choice. Experimental Hematology. 2004; 32(4):397-407.

2. Grewal SS, Barker JN, Davies SM, et al. Unrelated donor hematopoietic cell transplantation: marrow or umbilical cord blood? Blood. 2003; 101(11):4233-4244.

3. Gluckman E. Ten years of cord blood transplantation: from bench to bedside. British Journal of Haematology. 2009; 147(2):192-199.

4. Barker JN, Wagner JE. Umbilical cord blood transplantation for the treatment of cancer. Nature Reviews Cancer. 2003; 3(7):526-532.

5. Barker JN, Rocha V, Scaradavou A. Optimizing Unrelated Donor Cord Blood Transplantation. Biol. Blood Marrow Transplant. 2009; 15(1):154-161.

6. Rubinstein P, Dobrila L, Rosenfield RE, et al. Processing and cryopreservation of placental/umbilical cord blood for unrelated bone marrow reconstitution. Proc. Nati. Acad. Sci. USA. 1995; 92(22):10119-10122.

7. Alonso JM, Regan DM, Johnson CE, et al. A simple and reliable procedure for cord blood banking, processing, and freezing: St Louis and Ohio Cord Blood Bank experiences. Cytotherapy. 2001; 3(6):429-433.

8. Standarts for Cellular Therapy Product Services. 5th edition. AABB. Bethesda, 2010. $126 \mathrm{p}$.

9. Högman CF, Eriksson L, Hedlund K, et al. The Bottom and Top System: A New Technique for Blood Component Preparation and Storage . Vox Sanguinis. 1988; 55(4):211-217.

10. Ademokun JA, Chapman C, Dunn J, et al. Umbilical cord blood collection and separation for haematopoietic progenitor cell banking. Bone Marrow Transplantation. 1997; 19 (10):1023-1028.

11. Davey S, Armitage S, Rocha V, et al. The London Cord Blood Bank: analysis of banking and transplantation outcome. British Journal of Haematology. 2004; 125(3):358-365.

12. Donaldson C, Buchanan R, Webster J, et al. Development of a district Cord Blood Bank: a model for cord blood banking in the National Health Service. Bone Marrow Transplantation. 2000; 25(8):899-905.

13. Godinho MI, de Sousa ME, Carvalhais A, et al. Umbilical cord blood processing with the Optipress II blood extractor. Cytotherapy. 2000 ; 2(6):439-443.

14. Solves $P$, Mirabet V, Carbonell-Uberos F. et al. Automated separation of cord blood units in top and bottom bags using the Compomat G4. Clin Lab Haematol. 2006. - 28, ():3. - P. 202-207.

15. Solves $P$, Mirabet V, Planelles D. et al. Red blood cell depletion with a semiautomated system or hydroxyethyl starch sedimentation for routine cord blood banking: a comparative study. Transfusion. 2005; 45(6):867-873.

16. Tsang KS, LiK, Huang DP, et al. Dextran sedimentation in a semi-closed system for the clinical banking of umbilical cord blood. Transfusion. 2001; 41(3):344-352.

17. Lecchi L, Perego L, Garcea F, et al. Ten-year quality control of a semiautomated procedure of cord blood unit volume reduction. Transfusion. 2008 ; $49(3): 563-569$.

18. Armitage $S$, Fehily D, Dickinson A, et al. Cord blood banking: volume reduction of cord blood units using a semi-automated closed system. Bone Marrow Transplantation. 1999; 23(5):505-509.

19. Papassavas AC, Gioka V, Chatzistamatiou T, et al. A strategy of splitting individual high volume cord blood units into two half subunits prior to processing increases the recovery of cells and facilitates ex vivo expansion of the infused haematopoietic progenitor cells in adults. Int. J. Lab Hematol. 2008; 30(2):124-132.

20. Theunissen K, Boogaerts M, Lauweryns $L$, et al. Fully automated and reproducible cord blood processing using the Biosafe Sepax and Coolmix Devices. Abstracts of ASN Conference, San-Diego, 2003. 
21. Sowemimo-Coker SO, Andrade F, Kim A, et al. A simple filtration system for red blood cell depletion and volume reduction in routine processing of human umbilical cord blood. Vox Sanguinis. 2009; 96(2):138-145.

22. Umbilical cord blood. D. H. McKenna et al. Core Principles in cellular therapy. Ed. by JD Roback et al. AABB; Bethesda, 2008. Chapter 3: 47-72.

23. Nicoud IB, Clarke DM, Taber G, et al. Cryopreservation of umbilical cord blood with a novel freezing solution that mimics intracellular ionic composition. Transfusion. 2012; 52(9):2055-2062.

24. Orlov A. I. Neparametricheskoe tochechnoe i interval'noe ocenivanie harakteristik raspredelenija. [The Nonparametric point and interval estimation of the characteristics of the distribution]. Zavodskaja laboratorija - The factory laboratory, 2004; 70(5):65-70.

25. Hollander M, Wolfe D. Neparametricheskie metody statistiki: Russ. ed. [Nonparametric statistical methods]. Moscow, Finansy i statistika, 1983.518 p.

26. Verojatnost' i matematicheskaja statistika. Jenciklopedija [The probability and Mathematical Statistics]. / ed. by Ju.V. Prohorov. Moscow, Izdatel'stvo Bol'shaja Rossijskaja Jenciklopedija, 1999. 910 p.

27. Vlasov VV. Vvedenie v dokazatel'nuju medicinu [The introduction to evidence-based medicine]. Moscow, MediaSfera, 2001. $392 \mathrm{p}$

The authors indicate no potential conflicts of interest.

Received: February 16, 2014

Accepted: March 6, 2014

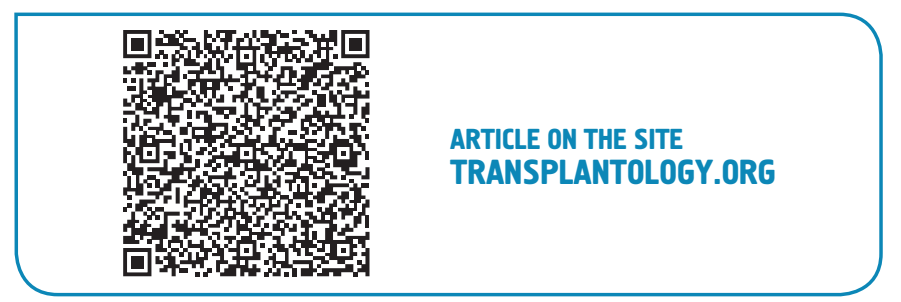

